\title{
The central diabetes insipidus associated with septo-optic dysplasia (de Morsier syndrome)
}

\author{
Centralna moczówka prosta współistniejącą z dysplazją przegrodowo-oczną (zespół Morsiera)
}

\author{
${ }^{1}$ Marta Hetman, ${ }^{1}$ Michał Fułek, ${ }^{1}$ Katarzyna Zajączkowska, ${ }^{1}$ Anna Żarczyńska, ${ }^{1}$ Piotr Łagosz, \\ ${ }^{2}$ Ewa Barg
}

\author{
'Students' Science Society, Wroclaw Medical University, Poland \\ ${ }^{2}$ Chair and Department of Basic Medical Sciences, Wroclaw Medical University, Poland
}

\begin{abstract}
Introduction: Septo-optic dysplasia (SOD) is a rare congenital heterogeneous malformation with postulated genetic and environmental etiology. Septo-optic dysplasia is characterized by classic triad: optic nerve hypoplasia, midline brain malformation and hypothalamic-pituitary endocrine deficiencies. The most common hormonal deficiencies affect growth hormone and gonadotropin but it can also be lower levels of the other hormones. The rarest form of hormone deficiency is the deficiency of the antidiuretic hormone. Case report: The boy was born in $39^{\text {th }}$ week of pregnancy in general good condition. Weakened suction reflex and spitting resulted in substantial difficulties with breastfeeding. After transfontanelle ultrasonography central nervous system defect was suspected. In the $5^{\text {th }}$ month of life MRI confirmed septo-optic dysplasia on the basis of anterior genu of corpus callosum and septum pellucidum agenesis, both optic nerves and optic chiasm hypoplasia, pachygyria and polimicrogyria of the right frontoparietal cortex. Neurological examination revealed axial laxity, psychomotor development delay, difficulties in keeping eyes fixed as well as rotary and horizontal nystagmus. At the age of 3 years he underwent the endocrinological consultation due to polydipsia and polyuria. The tests revealed lower urine specific gravity tests results, therefore diabetes insipidus was diagnosed. The boy still receives desmopressin and there are no signs of central diabetes insipidus. Currently, the boy is under a multi-disciplinary medical care.

Conclusions: The attention should be focussed on early diagnosis, mutli-specialized care and treatment SOD. Hypopituitarism ranges from isolated to multiple hormone deficits, with diabetes insipidus in a minority. Although rare, SOD is an important cause of congenital hypopituitarism and should be considered in all children with midline defects and optic nerve hyploplasia.
\end{abstract}

Key words:

congenital abnormalities, de Morsier's syndrome, septo-optic dysplasia, central diabetes insipidus, hypopituitarism.

\begin{abstract}
Streszczenie
Wstęp: Dysplazja przegrodowo-oczna (septo-optic dysplasia - SOD) jest rzadkim wrodzonym zaburzeniem z prawdopodobnym podłożem genetycznym i środowiskowym. Charakteryzuje się klasyczną triadą objawów: niedorozwojem nerwu ocznego, zaburzeniami rozwojowymi mózgu oraz niedoborami endokrynologicznymi pochodzenia podwzgórzowo-przysadkowego. Najczęściej spotykany jest niedobór hormonu wzrostu i gonadotropin, ale mogą występować także inne niedobory. Najrzadziej występuje niedobór hormonu antydiuretycznego.

Opis przypadku: Chłopiec urodzony w 39. tygodniu ciąży w stanie ogólnym dobrym. Wystąpiły trudności w karmieniu piersią z powodu osłabionego odruchu ssania i połykania. Na podstawie badania ultrasonograficznego przezciemieniowego głowy wysnuto podejrzenia wad rozwojowych ośrodkowego układu nerwowego. Wykonane w 5. miesiącu życia badanie rezonansem magnetycznym potwierdziło SOD u podstawy przedniego rogu ciała modzelowatego, niedorozwój międzykomorowej, obustronnie nerwów wzrokowych, a także skrzyżowania, pachygyria, niedorozwój kory czołowo-skroniowej. W badaniu neurologicznym wykazano zwichnięcie osiowe, opóźniony rozwój psychoruchowy, problem z utrzymaniem fiksacji wzroku z oczopląsem poziomym i obrotowym. W 3. roku życia opiekunowie chłopca zgłosili się z powodu występującego u niego wzmożonego pragnienia i oddawania moczu. W badaniach stwierdzono znacznie obniżone ciężary moczu, potwierdzając rozpoznanie moczówki prostej. Włączono leczenie desmopresyną, uzyskując znaczną poprawę. Aktualnie chłopiec wymaga wielospecjalistycznej opieki.
\end{abstract}

Wnioski: W przypadku podejrzenia SOD należy pamiętać o wczesnym rozpoznaniu, konieczności wielospecjalistycznej opieki i wdrożeniu odpowiedniego leczenia. Objawy niedoczynności przysadki mogą wynikać z izolowanego lub wielohormonalnych niedoborów, 
natomiast wyjątkowo rzadko rozpoznawana jest moczówka prosta. Dysplazja przegrodowo-oczna może być przyczyną wrodzonej niedoczynności przysadki. Należy pamiętać o możliwości wystąpienia takich objawów u dzieci z tym schorzeniem.

Słowa kluczowe:

wrodzone zaburzenia, zespół Morsiera, dysplazja przegrodowo-oczna, centralna moczówka prosta, niedoczynność przysadki.

\section{Introduction}

The term septo-optic dysplasia (SOD) was formed for the first time in 1956 by De Morsier [1], therefore the group of symptoms accompanying this condition is also referred as De Morsier syndrome. The septo-optic dysplasia is a rare congenital heterogeneous malformation with postulated genetic and environmental etiology with estimated incidence of 1/10000 in live births [2]. The septo-optic dysplasia is characterized by classic triad: optic nerve hypoplasia (including strabismus, nystagmus, amblyopia, blindness), midline brain malformation (absent septum pellucidum) and hypothalamic-pituitary endocrine deficiencies. Clinical diagnosis requires the presence of at least two characteristics and can be confirmed by ophthalmological examination, magnetic resonance imaging (MRI), and pituitary hormone analyses. The septooptic dysplasia is clinically heterogeneous disorder within which highly varied symptoms may occur including recurrent seizures, stereotypic movements, delayed development, visual and hearing impairment, anosmia, cardiovascular anomalies and sleep disturbance [3]. The most common hormonal deficiencies affect growth hormone and gonadotropin but it can also be lower levels of the other hormones originated from hypothalamus and hypophysis such as antidiuretic hormone, corticotropin or thyrotropic hormone. Among central nervous system corpus callosum dysgenesis, schizencephaly, microphthalmos, anophthalmia, olfactory tract hypoplasia were most often reported [4]. Diabetes insipidus (DI) is classified as central diabetes insipidus (CDI) and nephrogenic diabetes insipidus (NDI). Central diabetes insipidus is due to impaired production and/or secretion of the antidiuretic hormone (ADH) and this type of DI could be found in SOD. Insufficient level of ADH cause large amounts of diluted urine (polyuria), increased fluid intake (polydypsia), hypernatremia and hypokalemia. Undiagnosed DI or badly managed, is associated with a range of clinical symptoms such as severe volume depletion and electrolyte abnormalities. DI patients have an intact thirst mechanism, and therefore they are able to maintain normal serum osmolality and volume status without clinical symptoms other than polyuria and polydipsia. Volume depletion leads to hypotension, acute kidney injury, liver injury, muscle injury and shock [5]. The signs of hypertonic encephalopathy are: irritability, cognitive decline, disorientation, and confusion to decreased levels of consciousness, seizure and coma [6]. The main goal for treating DI is a correction of water deficit and a reduction in the ongoing water loss from the kidney. Desmopressin has been commonly used for treating CDI. Hyponatremia is a rare complication of desmopressin therapy, which can cause severe, even fatal sequelae [7], therefore, serum electrolytes need to be monitored during the desmopressin therapy. In most cases, SOD occurs de novo and is associated with a multifactorial etiology (complex genetic susceptibility and interaction of harm- ful environmental factors acting in the prenatal life). Familial cases are related to SOX2, SOX3, OTX2 and HESX1 mutations [3, 8-10]. Frequently suggested causes are bleeding during the first trimester of pregnancy, alcoholism and drug abuse during pregnancy, primiparity and young maternal age $[11,12]$.

In this case report we describe the association of central diabetes insipidus with SOD.

\section{Case report}

The boy was born as a first child on time, in $39^{\text {th }}$ week of first pregnancy by cesarean section (C-section). With 2550 grams birth weight, $49 \mathrm{~cm}$ body length, $30 \mathrm{~cm}$ head circumference and 10 points in Apgar scale he was in general good condition.

C-section was performed as a consequence of mother's genital tract infection. Neonatal period was complicated with intrauterine infection and jaundice, which was treated with phototherapy. Despite periparturient period (which was complicated by maternal reproductive tract infection), the pregnancy processed correctly. In the $3^{\text {rd }}$ month of pregnancy sinusitis was treated with antibiotics.

Weakened suction reflex and spitting resulted in substantial difficulties with breastfeeding, which lead to lack of gain weight. Hence the patient was hospitalized in the $1^{\text {st }}$ month of life. In the screening test the otoacoustic emission did not reveal any abnormalities. Laboratory tests have shown severe anemia which required blood transfusion. After neurological examination and transfontanelle ultrasonography central nervous system defect was suspected. In the fifth month of life MRI examination confirmed septo-optic dysplasia on the basis of anterior genu of corpus callosum and septum pellucidum agenesis, both optic nerves and optic chiasm hypoplasia, pachygyria and polimicrogyria of the right frontoparietal cortex. Neurological examination revealed axial laxity, psychomotor development delay, difficulties in keeping eyes fixed as well as rotary and horizontal nystagmus. EEG waveform was abnormal with infrequently occurring generalized seizures. Ophthalmological examination showed hypoplasia of the optic nerve, severe visual impairment in the left eye, refractive error $+2 \mathrm{D}$ in both eyes, horizontal nystagmus.

Due to the above the psychomotor development was significantly delayed. He has reached his developmental milestones: sitting by the end of 2 years old, crawling - 2.5 years old, walking -3 years old. He learnt how to mimic sounds and use simple words at the age of 3 . He had been rehabilitated with Vojta and Bobath methods until age of 3. He had demonstrated aggressive behavior towards his parents, autoaggression and behaviors from the spectrum of autism, including: spinning in cricles, flapping, covering ears with hands. 
Table I. The selected results of tests conducted during a 4-year observation in the pediatric endocrinologist office

\begin{tabular}{llllll}
\hline Number of visit & $1^{\text {st }}$ & $2^{\text {nd }}$ & $3^{\text {rd }}$ & $4^{\text {th }}$ & $5^{\text {th }}$ \\
\hline Parameters & \multicolumn{5}{l}{} \\
\hline Age & 3 years 5 months & 4 years 9 months & 5 years 5 months & 6 years 6 months & 7 years 1 month \\
\hline Urine gravity $(\mathrm{g} / \mathrm{l})$ & 1.003 & 1.003 & 1.009 & 1.014 & 1.014 \\
\hline $\mathrm{TSH}(\mathrm{N} / \mathrm{ml})$ & 2.11 & - & - & 1.64 & 1.67 \\
\hline $\mathrm{ft} 4(\mathrm{pmol} / \mathrm{l})$ & 1.49 & - & - & 1.20 & 1.23 \\
\hline Sodium $(\mathrm{mmol} / \mathrm{l})$ & - & 134 & 138 & 134 & - \\
\hline Potassium $(\mathrm{mmol} / \mathrm{l})$ & - & - & 4.4 & 4.8 & - \\
\hline Body weight $(\mathrm{kg})(\mathrm{pc})$ & $14.5\left(25^{\text {th }}\right)$ & $19\left(50^{\text {th }}\right)$ & $18\left(25^{\text {th }}-50^{\text {th }}\right)$ & $21\left(25^{\text {th }}\right)$ & $22\left(25^{\text {th }}\right)$ \\
\hline Body height $(\mathrm{cm})(\mathrm{pc})$ & $93.5\left(<3^{\text {rd }}\right)$ & $101.6\left(<3^{\text {rd }}\right)$ & $104\left(<3^{\text {rd }}\right)$ & $110\left(<3^{\text {rd }}\right)$ & $112.4\left(<3^{\text {rd }}\right)$ \\
\hline BMl $(\mathrm{pc})$ & $16.6\left(50^{\text {th }}-57^{\text {th }}\right)$ & $18.4\left(90^{\text {th }}-97^{\text {th }}\right)$ & $16.6\left(75^{\text {th }}\right)$ & $17.5\left(75^{\text {th }}-90^{\text {th }}\right)$ & $17.4\left(75^{\text {th }}-90^{\text {th }}\right)$ \\
\hline
\end{tabular}

At the age of 3 years and 5 months he underwent the endocrinological consultation due to polydipsia, polyuria and anxiety. During taking medical history the suspicion of de Morsier syndrome has been put forward. The boy drank about 6 I of fluids daily, during nights 5 diapers were used on average. Further genetic diagnosis was planned and testing for diabetes insipidus was ordered. In the physical examination boy's weight stood at $14.5 \mathrm{~kg}$ and his height at $93.5 \mathrm{~cm}\left(3^{\text {rd }} \mathrm{pc}\right.$; mother's height: $174 \mathrm{~cm}$, father's: $183 \mathrm{~cm}$ ). Polish growth charts [13] were used to assess growth development. Urine specific gravity tests $(\mathrm{x} 3)$; TSH level; analysis of lipids; fasting, 1 and 2 hours after eating glucose test were prescribed.

The tests revealed lower urine specific gravity $(1,004 ; 1,003$; $1,004 \mathrm{~g} / \mathrm{ml})$, therefore diabetes insipidus was diagnosed. The levels of TSH, lipids and glucose were within the normal range (Table I). Diabetes mellitus was excluded as the cause of polydipsia and polyuria. Minirin (desmopressin) $60 \mathrm{mg}$ has been prescribed in initial doses $4 \times 15 \mathrm{mg}$, which effectively relieved symptoms of DI. Subsequently the doses were adjusted due to blood sodium levels. On the next consultations further abnormalities were reported: long urination intervals, strabismus and poor verbal contact. At the age of 6 years and 6 months the boy still didn't control urine passing (diapers needed), progressing vision impairment (foresight), trend towards constipations. The boy remains under endocrinological assessment.

Being 3 years and 8 months old he underwent genetic consultation. In the cytogenetic test on peripheral blood lymphocytes a normal male karyotype 46XY was demonstrated. Numerical disorders of the chromosomes and big structural abnormalities were excluded. At that time the boy's height was $92 \mathrm{~cm}\left(<3^{\text {rd }} \mathrm{pc}\right)$, weight equaled $14.3 \mathrm{~kg}\left(10^{\text {th }} \mathrm{pc}\right)$ and head circumference was $50 \mathrm{~cm}\left(25^{\text {th }}\right.$ pc; Figs. 1, 2). Parents received recommendations to continue neurological, ophthalmological and endocrinological care, stimulate their child development and hearing assessment.

At the age of 3 years and 9 months boy sustained head trauma without loss of consciousness and with the presence of vomiting. During hospitalization due to the trauma there was no sign of skull fracture in X-ray image. However, in a short time, epileptic seizure occurred (hypertonia, dilated pupils, unresponsiveness to stimuli were observed). After rectal administration of diazepam symptoms subsided and have not returned. Neurological examination after the episode of seizure showed: somnolence, horizontal nystagmus, symmetrical pupils responding to light, global hypotonia, deep tendon reflexes in the norm, absence of pyramidal and meningeal symptoms. During 15 minutes EEG recording the physiological sleep was not achieved. Numerous motor and muscle artifacts hindered the interpretation of the examination. Attempt failed due to the uncooperative child. In the short periods without artifacts seizures weren't detected. MRI image did not show any new findings, and because of that, the diagnosis of epilepsy could not be made Low sodium levels $(126 \mathrm{mmol} / \mathrm{l}$, the next day $134 \mathrm{mmol} / \mathrm{l})$ were detected in the hospital. Hiponatremia was observed at admission, presumably due to Minirin treatment. After stabilization of electrolyte disturbances and modification of desmopressin treatment, the symptoms let up. During the hospitalization, spectroscopy revealed voxels localised in the posterior and anterior parts of the frontal lobes and cingulate gyrus. In voxels localised in the anterior parts of the frontal lobes high choline level $(\mathrm{Cho} / \mathrm{Cr})$ was observed (left side 1.2; right side 1.16), slightly increased also in the voxel in the posterior part of the left frontal lobe.

Currently, the boy is under a multi-disciplinary medical care. There are no signs of central diabetes insipidus. The boy requires further observation, and in the future, assessment of the functioning of the hypothalamic-pituitary axis, in particular the assessment of growth hormone deficiency and gonadotropin deficiency. 


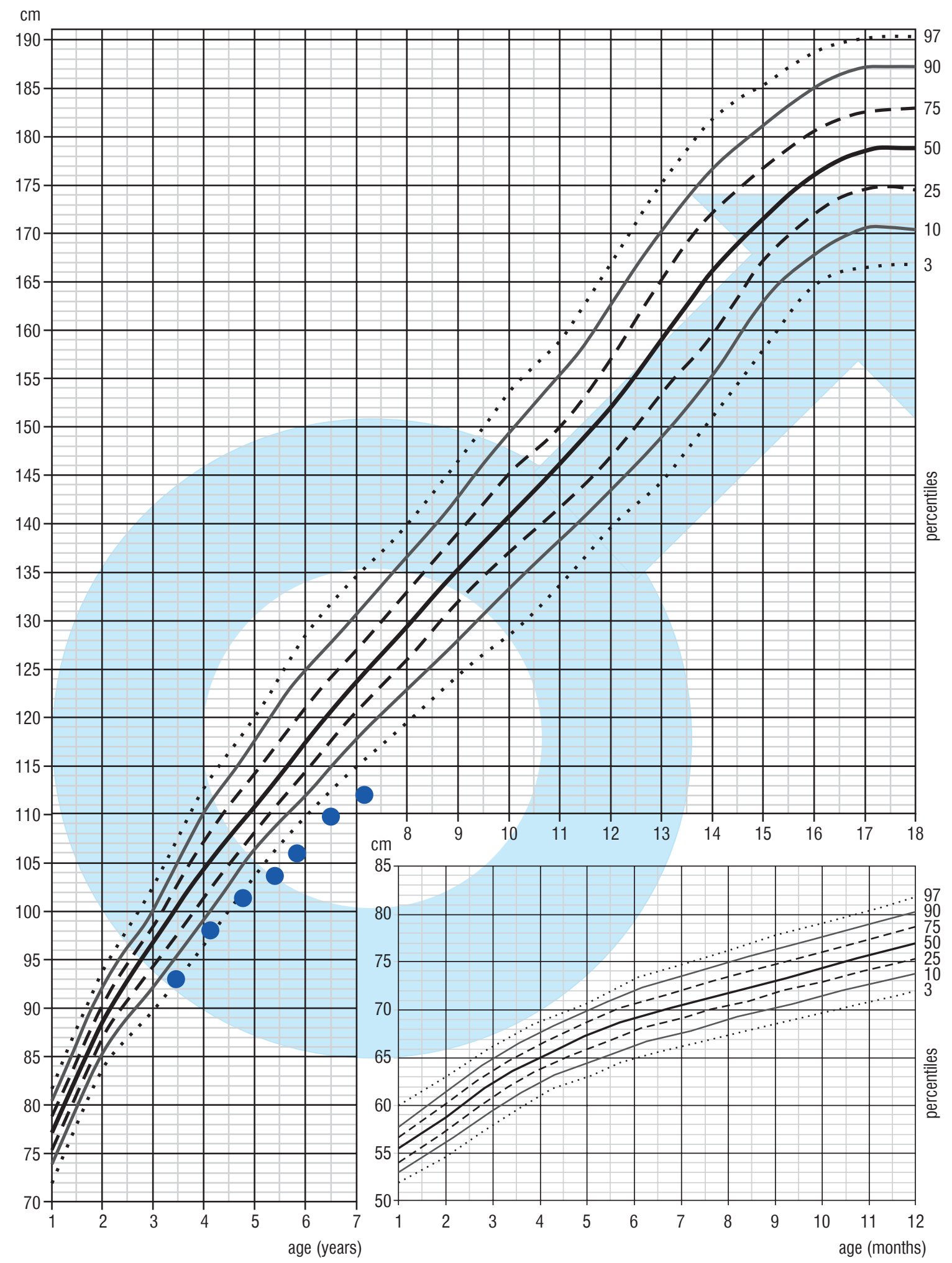

Figure 1. The growth rate of the boy (from 3.5 years old to 7 years old) 


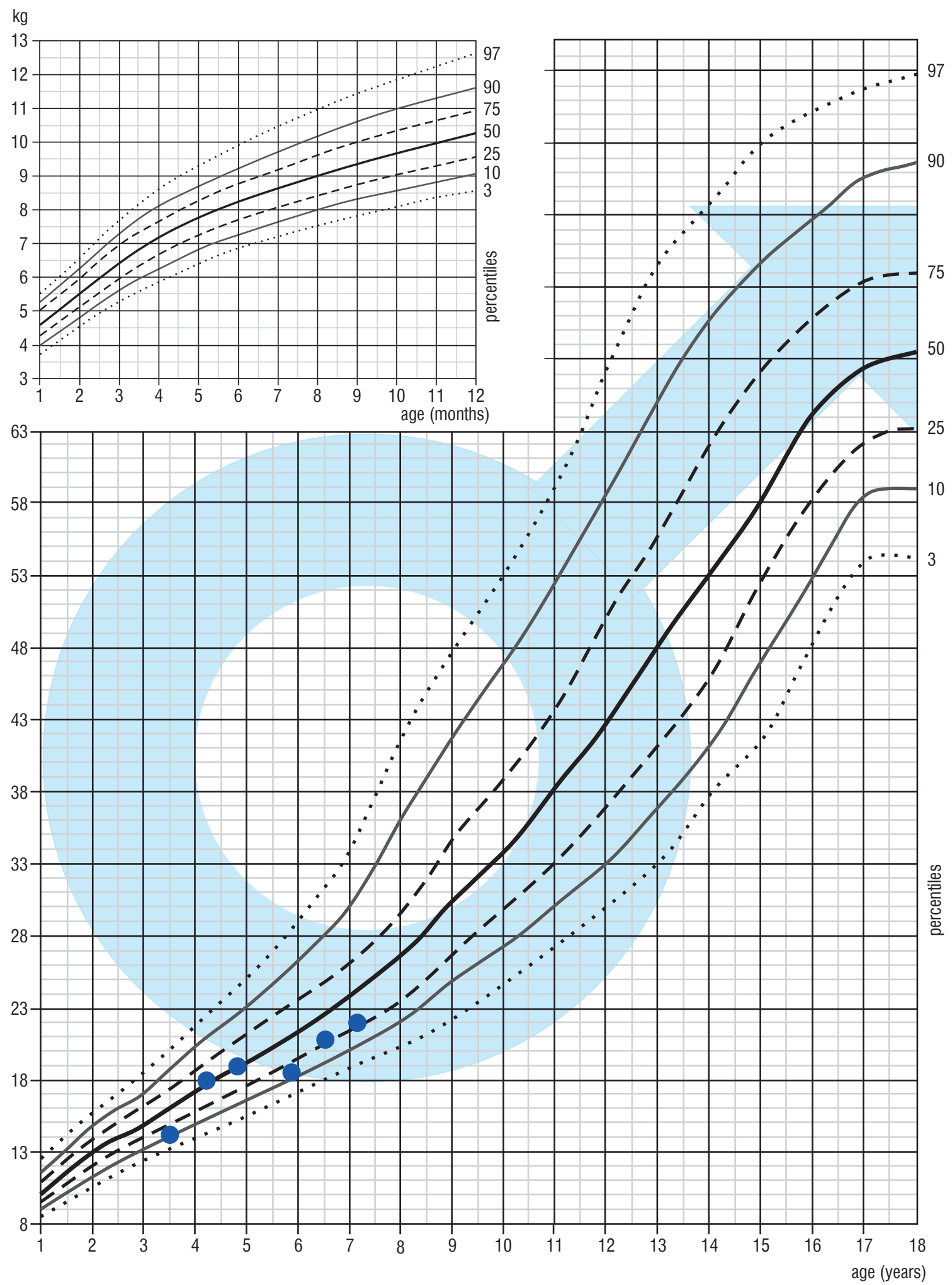

Figure 2. The boy's body mass chart (from 3.5 years old to 7 years old) 


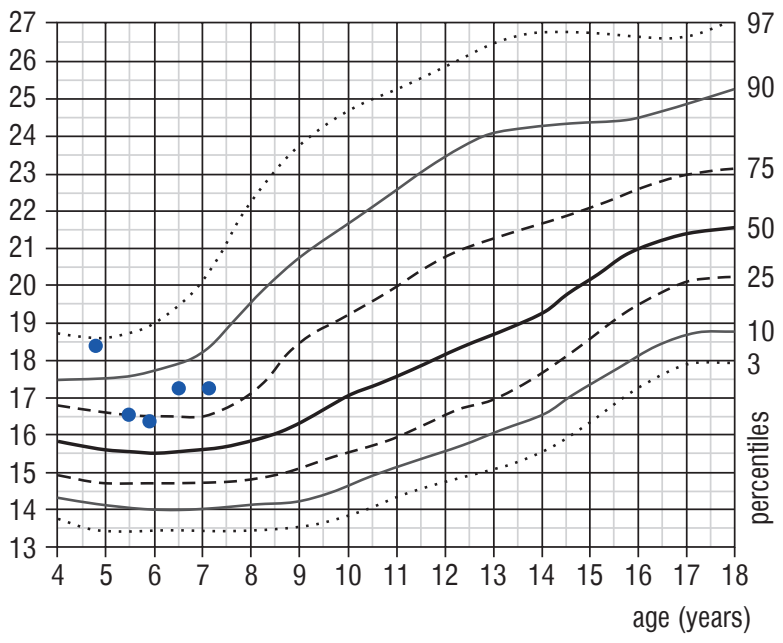

Figure 3. The boy's body mass index chart (from 4.5 years old to 7 years old)

\section{Discussion}

Septo-optic dysplasia (de Morsier Syndrome) is a rare syndrome itself. The syndrome is characterized by a significant diversity of the phenotype. Thomas et al. [14] emphasized that only $30 \%$ of the patients present with the complete triad of optic nerve hypoplasia, midline central nervous system malformations and pituitary dysfunction. Concerning phenotypic variability, people suffering from SOD require multi-specialized care. The risk of hypothalamic-pituitary dysfunction in SOD is highest below 2 years of age and when both optic nerve hypoplasia and dysgenesis of septum pellucidum/corpus callosum are present [15]. Cemeroglu et al. analyze eighty children with SOD: $96 \%$ had optic nerve hypoplasia on MRI and were diagnosed due to visual issues including nystagmus (36\%) or strabismus (13.8\%). 51\% had hypothalamic-pituitary dysfunction, when optic nerve hypoplasia was present with (36\%) or without (15\%) dysgenesis of septum pellucidum and/or corpus callosum compared to dysgenesis of septum pellucidum and/or corpus callosum alone (4\%) [15].

The boy presented in this case report exhibits all three features of SOD: optic nerve hypoplasia (both optic nerves and optic chiasm hypoplasia, resulting in amblyopia, hyperopia and strabismus), midline brain malformation (anterior genu of corpus callosum and septum pellucidum agenesis) and hypothalamic-pituitary endocrine deficiencies (growth deficiency, central diabetes insipidus).

Central hypothyroidism and growth hormone deficiency were most common followed by secondary/tertiary adrenal insufficiency and diabetes insipidus [15]. The occurrence of vasopressin-related pituitary disorders seems to be extremely sporadic in this syndrome. Malinowska et al. [16] presented a description of 6 pediatric patients with SOD. Six of them were diagnosed with secondary hypothyroidism, the next six with $\mathrm{GH}$ deficiency, three with secondary adrenal insufficiency, one with LH and FSH deficiency, and one with central diabetes insipidus [16]. The CT or MRI of the head revealed: 4 agenesis of the septum pellucidum, 2 hypoplasia of the corpus callosum, 1 lack of septum pellucidum and hypoplasia of the corpus callosum, 1 hypoplasia of the anterior lobe and ectoplasm of the posterior pituitary lobe, without other pathologies of the middle line of the brain [17]. In this case report, the boy presented growth deficiency (boy's hight below $3^{\text {rd }}$ percentile despite a very good growth potential - father's height $183 \mathrm{~cm}$, mother's height $174 \mathrm{~cm}$ ), however we do not have knowledge, whether specific tests were conducted. Assessment of gonadotropin level disorders is currently not possible, due to the fact that the boy is still before puberty. Vigilant observation and rapid response are required if the first signs of puberty do not appear at the proper time.

After the diagnosis of SOD, many clinicians pay attention to the diagnosis of growth hormone secretion and gonadotropin secretion, forgetting about the possibility of other disorders. The boy described in our case report was referred to the endocrine clinic, because the attention of the boy's parents drew increased thirst and a large amount of urine output. The patient drank about 6 liters of fluid a day, simultaneously using up to 9 pampers in one night. During endocrinological consultation, the doctor paid attention to dry mucous membranes, which may indicate some degree of dehydration. The clinical picture obtained during the examination and the parents' interview suggested a suspicion of diabetes insipidus.

The basic and simplest test confirming the diagnosis of DI is a general urine test, which includes urine specific gravity. The patient was asked to perform three times the examination of urine specific gravity, the significant reduction of which confirmed the diagnosis. The introduction of treatment (desmopressin) effectively eliminated the symptoms of central diabetes insipidus. DI, if well balanced by the amount of fluids consumed, may initially not reveal clinical symptoms other than polydipsia and polyuria. However, when fluid intake is insufficient, electrolyte disturbances appear.

A patient with SOD should be treated with great involvement of clinicians and the environment. The boy described in this case requires systematic monitoring of specific urine weights, daily diuresis and the amount of liquids consumed per day. Continuous monitoring of the growth rate seems to be no less important. The boy also requires psychological, neurological and speech therapy rehabilitation due to the delay of development.

\section{Conclusions}

The attention should be focused on early diagnosis, treatment and education of clinicians how to recognize SOD. Abnormalities in people with SOD can vary in the severity of clinical presentation and phenotype, therefore, they require multi-specialized care. Hypopituitarism ranges from isolated to multiple hormone deficits, with diabetes insipidus in a minority. Although rare, SOD is an important cause of congenital hypopituitarism and should be considered in all children with midline defects and optic nerve hyploplasia. Pituitary insufficiency may evolve over time, therefore children with SOD must be kept under endocrine follow-up. Children suffering from SOD should have development support, including motor rehabilitation, sensory and speech therapy integration. 


\section{References}

1. de Morsier G. Études sur les dysraphies, crânioencéphaliques. III. Agénésie du septum palludicum avec malformation du tractus optique. La dysplasie septo-optique. Schweizer Archiv für Neurologie und Psychiatrie, Zurich 1956, 77: 267-292.

2. Patel L, McNally RJ, Harrison E, et al. Geographical distribution of optic nerve hypoplasia and septo-optic dysplasia in Northwest England. J Pediatr 2006;148: 85-88. doi: 10.1016/j.jpeds.2005.07.031

3. Webb EA, Dattani MT. Septo-optic dysplasia. Eur J Hum Genet 2010; 18: 393-397.

4. Haddad NG, Eugster EA. Hypopituitarism and neurodevelopmental abnormalities in relation to central nervous system structural defects in children with optic nerve hypoplasia. J Pediatr Endocrinol Metab 2005; 18: 853-858.

5. Lu HAJ. Diabetes Insipidus. Adv Exp Med Biol 2017; 969: 213-225. doi: 10.1007/978-94-024-1057-0 14

6. Alharfi IM, Stewart TC, Kelly SH, et al. Hypernatremia is associated with increased risk of mortality in pediatric severe traumatic brain injury. J Neurotrauma 2013; 30: 361-366. doi: 10.1089/neu.2012.2410

7. Verrua E, Mantovani G, Ferrante E, et al. Severe water intoxication secondary to the concomitant intake of non-steroidal anti-inflammatory drugs and desmopressin: a case report and review of the literature. Hormones (Athens) 2013; 12: 135-141.

8. Dattani MT, Martinez-Barbera JP, Thomas PQ, et al. Mutations in the homeobox gene HESX1/Hesx1 associated with septo-optic dysplasia in human and mouse. Nat Genet 1998; 19: 125-133. doi: $10.1038 / 477$
9. Kelberman D, Rizzoti K, Avilion A, et al. Mutations within Sox2/SOX2 are associated with abnormalities in the hypothalamo-pituitary-gonadal axis in mice and humans. J Clin Invest 2006; 116: 2442-2455. doi: $10.1172 / \mathrm{JCl} 28658$

10. Kelberman D, de Castro SC, Huang S, et al. SOX2 plays a critical role in the pituitary, forebrain and eye during human embryonic development. J Clin Endocrinol Metab 2008; 93: 1865-1873. doi: 10.1210/jc.2007-2337

11. Garcia ML, Ty EB, Taban M, et al. Systemic and ocular findings in 100 patients with optic nerve hypoplasia. J Child Neurol 2006; 2013: 949-956. doi: 10.1177/08830738060210111701

12. Atapattu N, Ainsworth J, Willshaw H. Septo-optic dysplasia: antenatal risk factors and clinical features in a regional study. Horm Res Paediatr 2012; 2013: 81-87. doi: 10.1159/000341148

13. Palczewska I, Niedźwiecka Z. Siatki centylowe do oceny rozwoju somatycznego dzieci i młodzieży. Zakład Rozwoju Dzieci i Młodzieży Instytutu Matki i Dziecka. Warszawa 1999. [http://i.wp.pl/a/i/ szkola2/pdf/siatki_centylowe.pdf (status at 12.12.18).

14. Thomas PQ, Dattani MT, Brickman JM, et al. Heterozygous HESX1 mutations associated with isolated congenital pituitary hypoplasia and septo-optic dysplasia. Hum Mol Genet 2001; 10: 39-45.

15. Cemeroglu AP, Coulas T, Kleis L. Spectrum of clinical presentations and endocrinological findings of patients with septo-optic dysplasia: a retrospective study. J Pediatr Endocrinol Metab 2015; 28 : 1057-1063. doi: 10.1515/jpem-2015-0008

16. Malinowska A, Ginalska-Malinowska M, Gajdulewicz M. Endocrine disorders in septo-optic dysplasia. Pediatric Endocrinology (Supplements) 2009; 8 (8). 